Int. J. Electrochem. Sci., 16 (2021) Article ID: 210644

International Journal of

ELECTROCHEMICAL

SCIENCE

www.electrochemsci.org

\title{
Analytical Solution of Non Linear Problems in Homogeneous Reactions Occur in the Mass-Transfer Boundary Layer: Homotopy Perturbation Method
}

\author{
Rajagopal Swaminathan ${ }^{1}$, R. Saravanakumar ${ }^{3}$, Kothandapani Venugopal $^{2}$, L. Rajendran $^{4, *}$ \\ ${ }^{1}$ Department of Mathematics, VidhyaaGiri College of Arts and Science, Sivaganga - 630108, India \\ ${ }^{2}$ PG, Research \& Department of Mathematics, Govt Arts College (Affiliated to Bharathidasan \\ University), Kulithalai - 639120, India \\ ${ }^{3}$ Department of Mathematics, Anna University, University college of Engineering, Dindigul, India \\ ${ }^{4}$ Department of Mathematics, AMET (Deemed to be university), Kanathur, Chennai, India \\ *E-mail: raj_sms@ rediffmail.com
}

doi: $10.20964 / 2021.06 .51$

Received: 3 February 2021/ Accepted: 27 March 2021/ Published: 30 April 2021

\begin{abstract}
Mathematical models for mass transfer accompanied by a reversible homogeneous chemical reaction are discussed. This model is based on a system of nonlinear equations containing a nonlinear term related to reversible homogeneous reactions. When reactions arise in the mass-transfer boundary layer, the measurement of mass transfer to and from electrodes frequently needs the species concentrations. We can obtain the concentration of species by solving the nonlinear equations using the homotopy perturbation method. Our approximate analytical results are also compared with the simulation result. A satisfactory agreement is observed between our analytical and simulation results. The approximate analytical expression obtained here can be used to estimate the system's dynamical behaviour. The influence of the parameters on concentration is discussed and presented graphically.
\end{abstract}

Keywords: Mathematical modeling, Nonlinear equations, Homotopy perturbation method, Reversible homogeneous reactions.

\section{$\underline{\text { FULL TEXT }}$}

(C) 2021 The Authors. Published by ESG (www.electrochemsci.org). This article is an open access article distributed under the terms and conditions of the Creative Commons Attribution license (http://creativecommons.org/licenses/by/4.0/). 